\title{
Kinetic modeling of Shewanella baltica KB30 growth on different substrates through respirometry
}

\author{
Juan Carlos Leyva-Díaz ${ }^{1,2,3}$, José Manuel Poyatos ${ }^{1,2}$, Paolo Barghini ${ }^{3}$, Susanna Gorrasi ${ }^{3}$ \\ and Massimiliano Fenice ${ }^{3,4^{*}}$ (1)
}

\begin{abstract}
Background: Shewanella baltica KB30 was isolated from seawater collected in Kandalaksha Bay, White Sea (Russia). This strain is known for its ability to grow on a pool of different substrates, including carbohydrates, carboxylic and amino acids, and lipids. However, no data are available on its metabolic efficiency in relation to the use of different carbon sources typologies. This work represents the first attempt to characterize S. baltica by its heterotrophic kinetic performance.
\end{abstract}

Results: Growth and substrate consumption, during the biodegradation of sodium acetate, glucose, tween 80 and peptone, were analyzed through a respirometric method. To find the model best fitting the experimental data and to obtain the kinetic parameters, the equations of Monod, Moser, Contois and Tessier were applied. The kinetic behavior of S. baltica was fitted to Monod model for sodium acetate and tween 80 , while it was adjusted to Contois model for glucose and peptone. In this regard, peptone was consumed faster than the other substrates, as indicated by the highest values of substrate degradation rate, which exceeded $60 \mathrm{mg} \mathrm{O}_{2} \mathrm{~L}^{-1} \mathrm{~h}^{-1}$.

Conclusions: Proteolytic metabolism was favored than lipidic and glucidic metabolism, which could contribute much more to mineralization and recycling of proteins than lipids and carbohydrates.

Keywords: Carbon utilization, Kinetics, Modeling, Shewanella baltica

\section{Background}

Shewanella was proposed as a new genus in 1985 and it was named in honor of James Shewan, as acknowledgment of his contributions to fisheries microbiology [1,2]. This genus belongs to the family Shewanellaceae, order Alteromonadales, within the $\gamma$-Proteobacteria class [3, 4]. These bacteria are motile Gram-negative rods and $\mathrm{H}_{2} \mathrm{~S}$-producers; in general, they are non-fermenting bacteria, although glucose fermentation has been reported $[5,6]$.

Mesophilic, psychrotolerant, psychrophilic or barophilic Shewanella species have been isolated from various

\footnotetext{
*Correspondence: fenice@unitus.it

${ }^{3}$ Department of Ecological and Biological Sciences, University of Tuscia, Largo Università snc, 01100 Viterbo, Italy

Full list of author information is available at the end of the article
}

habitats $[7,8]$. One of the most representative psychrotolerant (psychrotrophic) species is Shewanella baltica [9], which is widespread in marine environments and has been isolated from some fresh and ice-stored fish $[10,11]$. Shewanella species, in particular S. baltica, together with other specific spoilage organisms (i.e. Pseudomonas spp.), are involved in the spoilage of seafood products causing offensive off-flavors and the production of toxic compounds [12-14]. S. baltica is the most represented species among $\mathrm{H}_{2} \mathrm{~S}$-producing organisms in stored marine fish and has the capacity to produce signal compounds to facilitate the potential spoilage activity $[7,14]$.

Many works dealt with the metabolic competences of Shewanella, some studies extensively investigated its metabolism using both phenotypic methods (i.e. Biolog Microarray and API) and-omic sciences; substrate utilization by this genus and the related pathways had been 
mapped [15] together with various complete genomes [16] supplying a detailed insight of its ecophysiology and adaptive evolution. Phenotypic tests permit to verify the congruence between predicted and observed phenotype, and to understand the actual ability to utilize a single substrate.

However, one of the basic tools in microbiology is the study of the relationships between the use of different substrates and the relative specific growth rate, giving information on the efficiency of substrate consumption in relation to different metabolic strategies. This kind of investigation, possibly supported by adequate kinetic modeling, is helpful to understand the microbial approach in its primary metabolism and to predict possible biodegradation of organic compounds in natural and engineered environments [17].

In this context, a very useful tool is respirometry which allows indirect assessment of the aerobic metabolism of a given substrate by monitoring the biological oxygen consumption under well-defined conditions. Estimation of the kinetic parameters, through exogenous oxygen uptake rate curves, is also obtained. This method consists of measuring the dissolved oxygen (DO) concentration after the addition of determined amounts of substrate into the system $[18,19]$. In other words, respirometry measures the "speed" of substrate consumption; comparison of respirometric experiments, carried out on different substrates, supplies information somehow regarding the "preferred and or favored" microorganism's metabolism. This information is not given by the techniques mentioned above.

It is worth noting that, for Shewanella strains, there is a lack of predictive kinetic studies: only a few works modeled their kinetic performance concerning different substrate consumption [20,21]. Moreover, to the best of our knowledge, no study based on respirometric methods is available for S. baltica.

Shewanella baltica KB30, isolated from seawater collected at the Arctic Circle (Kandalaksha Bay, White Sea, Russia) has been previously investigated for some physiological and metabolic competences $[8,22]$. The strain showed an uncommon adaptation to temperature variations, growing from 0 to over $35^{\circ} \mathrm{C}$, but above all, revealing optimal or sub-optimal growth in a very wide range of temperatures $\left(15-30{ }^{\circ} \mathrm{C}\right)$, reflecting adaptation to the environmental peculiarities of that sub-extreme region [8]. In view of potential applications, together with those of other bacteria from same area, its substrate utilization pattern was profiled using the Biolog Microarray System [22].

The aim of the present study was to provide a more clear understanding of the primary metabolic strategies of this new cold-adapted strain of S. baltica on selected substrates. Thus, in this work, the aerobic heterotrophic kinetics of strain KB30 was studied by respirometry using different models (Monod, Moser, Contois and Tessier) to compare the consumption rate of various organic substrates and to predict bacterial biomass production. Respirometric experiments were carried out in a stirred tank bioreactor under controlled batch conditions.

\section{Methods}

\section{Microorganism and culture conditions}

The strain of S. baltica KB30 used in this study was isolated in a previous work from seawater collected in Kandalaksha Bay (White Sea, Russia) [8], maintained at $4{ }^{\circ} \mathrm{C}$ in the microorganism culture collection of DEB (Department of Ecological and Biological Sciences, University of Tuscia) and sub-cultured on plate count agar (PCA, Difco, USA) slants when necessary.

\section{Bioreactor inoculum preparation}

Biomass for liquid cultures (pre-inoculum) was obtained in PCA plates (incubated at $20{ }^{\circ} \mathrm{C}$ for $24 \mathrm{~h}$ ), from PCA slants, by the streak method. After incubation, biomass was recovered by sterile spatulas and transferred into $250 \mathrm{~mL}$ Erlenmeyer flasks filled with $50 \mathrm{~mL}$ of $\mathrm{M} 9$ minimal saline medium supplemented with $10 \mathrm{~g} \mathrm{~L}^{-1}$ of glucose. Flasks were then incubated at $20{ }^{\circ} \mathrm{C}$ and $150 \mathrm{rpm}$ in an orbital shaker $(24 \mathrm{~h})$ to obtain the adequate cell density $\left(\mathrm{OD}_{600}=6.0\right)$. Biomass from flasks was then harvested by centrifugation (7000 rpm for $10 \mathrm{~min}$ ), washed twice with M9 (without glucose), re-suspended in $10 \mathrm{~mL}$ of the same medium and added to the bioreactor to a cell density of ca. $0.3\left(\mathrm{OD}_{600}\right)$. Cell density, used for both the flask and bioreactor cultures, was measured through spectrophotometry $\left(\mathrm{OD}_{600}\right)$. The calibration curve was done with bacterial counts.

\section{Experimental system and respirometric assays}

The bioreactor used for the respirometric experiments consisted of an Applikon $3 \mathrm{~L}$ (total volume) autoclavable stirred tank reactor controlled by an ADI 1010 Bio Controller and an ADI 1025 Bio Console (Applikon Dependable Instruments BV, NL). The bioreactor was equipped with autoclavable polarographic DO (Ingold, $\mathrm{CH}$ ) and $\mathrm{pH}$ (Hamilton, USA) probes (Fig. 1a). The ADI 1010 Bio Controller was set up for automatic temperature $\left(20.0 \pm 0.1{ }^{\circ} \mathrm{C}\right)$ and stirrer speed control $(300 \mathrm{rpm}$, six-bladed Rushton-type impellers). Aeration was maintained at $1.0 \mathrm{vvm}$ by a rotameter. Since $\mathrm{pH}$ in the bioreactor was stable throughout the experiment $(7.25 \pm 0.50)$, $\mathrm{pH}$ control was not necessary.

One liter of M9 was prepared, transferred to the bioreactor, inoculated as reported above and aerated for $4 \mathrm{~h}$ to achieve a stable DO concentration. 


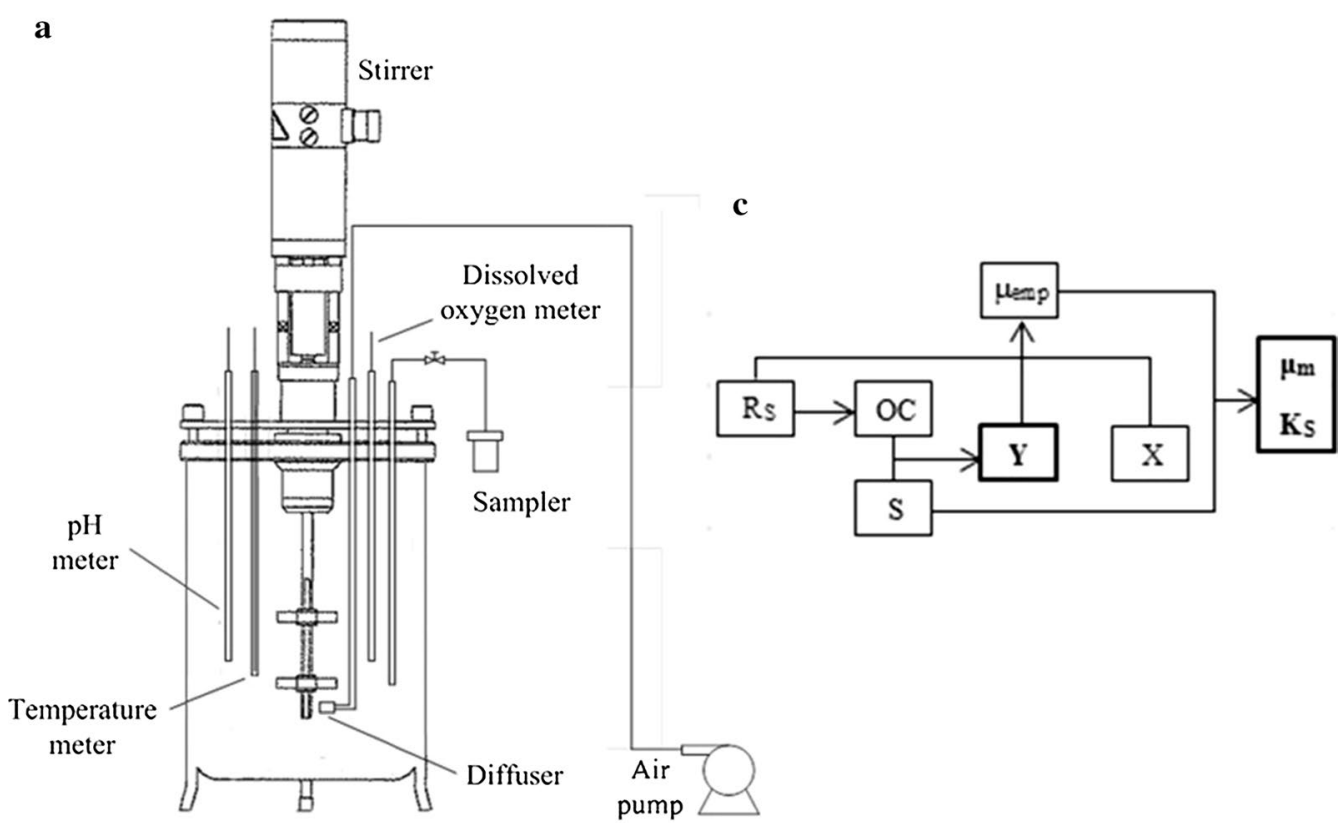

b

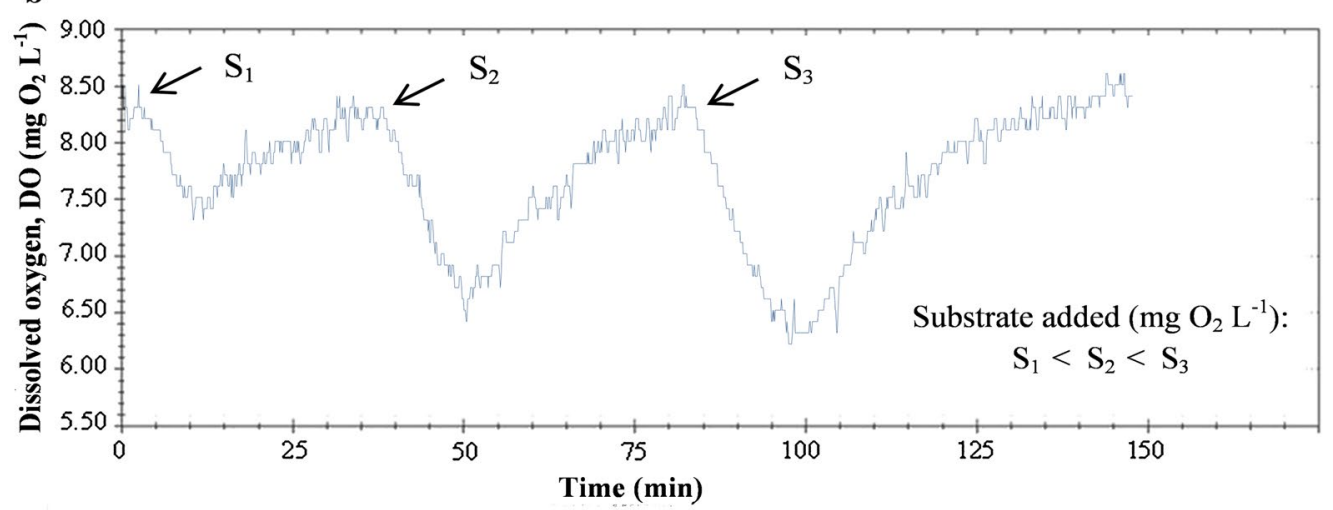

Fig. 1 Schematic diagram of the bioreactor used in the respirometric experiments (a); evolution of dissolved oxygen (DO) (b) and schematic diagram of the assessment of the kinetic parameters for the biodegradation of different substrates by Shewanella baltica KB30: yield coefficient ( $\mathrm{Y}$ ), substrate concentration $S$, biomass concentration $(X)$, oxygen consumption $(\mathrm{OC})$, maximum specific growth rate $\left(\mu_{\mathrm{m}}\right)$, empirical specific growth rate $\left(\mu_{\text {emp }}\right)$, dynamic oxygen uptake rate $\left(R_{s}\right)$ and substrate half-saturation coefficient $(K s)(\mathbf{c})$

Bioprocess parameters $(\mathrm{pH}, \mathrm{DO}$, agitation and temperature) were acquired using Biowatch software (Applikon Dependable Instruments BV, NL).

Respirograms show the consumption of DO as a result of bacterial respiratory metabolism in relation to a given carbon source. For the accurate characterization of bacterial heterotrophic kinetic behavior, in relation to the different nutrients, different concentrations of the same substrate are required. Due to the microbial metabolism, each addition of organic substrate should produce a DO decrease to a minimum value. Then, DO must increase again until a stable value is reached, which is achieved when the organic substrate is totally metabolized
(Fig. 1b). The use of diverse substrates is important to evaluate different rates of respiratory metabolism [23, 24]. During respirometric experiments cultures were under limited but not limiting carbon source conditions.

Stock solutions of sodium acetate $\left(5.0 \mathrm{~g} \mathrm{~L}^{-1}\right)$, glucose $\left(2.5 \mathrm{~g} \mathrm{~L}^{-1}\right)$, tween $80\left(0.2 \mathrm{~g} \mathrm{~L}^{-1}\right)$ and peptone $\left(1.0 \mathrm{~g} \mathrm{~L}^{-1}\right)$ were prepared in order to establish the same gradient of substrate concentration (S). Since S. baltica KB30 can use for its growth a very differentiated pattern of carbon sources, including organic acids, sugars, lipids and amino acids [22], the substrates for respirometric investigations had been chosen as prototypic compounds of principal cell metabolism (glucidic, proteolytic and lipolytic). As 
required by the kinetic method, the concentration of the different organic substrates was expressed as the chemical oxygen demand (COD) $\left(\mathrm{mg} \mathrm{O}_{2} \mathrm{~L}^{-1}\right)$, determined in accordance with standard methods [25].

The respirometric tests for S. baltica KB30 were carried out using three different concentrations of each substrate $\left(\mathrm{S}_{1}, \mathrm{~S}_{2}\right.$ and $\left.\mathrm{S}_{3}\right)$ prepared by diluting the stock solutions (35, 70 and $100 \%$, respectively). For the various substrates, $10 \mathrm{~mL}$ of each dilution were added in sequence to the inoculated M9 when DO reached a maximum steady level (Fig. 1b), sign of total substrate consumption by KB30. Corn steep liquor $(0.1 \mathrm{~mL})$ was added to each experiment to improve cell growth. The experiments were carried out in triplicate.

The time course of DO, measured as percentage saturation, was monitored and converted into respirograms (time course of DO concentration) corresponding to the different kinetic experiments related to sodium acetate, glucose, tween 80 and peptone (Fig. 2).

\section{Kinetic modeling}

For a more comprehensive characterization of the heterotrophic kinetics, the models of Monod, Moser, Contois and Tessier were applied and compared. These models allowed adjustment of the process kinetics for the different substrates tested. In this regard, the purpose of using different models was to understand which one permitted a more efficient empirical interpretation of the biodegradation of the various substrates since each model is fitted to a different kinetic behavior. The best fitting model for the experimental data was chosen based on the lowest least-squared error (LSE) between empirical and theoretical data:

$$
\sum_{\mathrm{i}=1}^{\mathrm{n}}\left(\mu_{\text {theoretical }}-\mu_{\text {emprical }}\right)^{2} .
$$

In light of this, the weighted sum of squares of differences between the empirical and theoretical values was minimized to yield the most appropriate kinetic parameters for the considered model [26]. In order to compare the efficiency of the different models, the empirical specific growth rate $\left(\mu_{\text {empirical }}\right)$ was calculated from the respirograms obtained for each substrate.

The respirometric experiments permitted the estimation of the following kinetic parameters: yield coefficient referred to the total suspended solids (TSS), $\mathrm{Y}_{\mathrm{TSS}}$ ( $\mathrm{mg}$ TSS $\mathrm{mg} \mathrm{COD}^{-1}$ ), maximum specific growth rate, $\mu_{\mathrm{m}}\left(\mathrm{h}^{-1}\right)$ and substrate half-saturation coefficient, $\mathrm{K}_{\mathrm{S}}$ $\left(\mathrm{mg} \mathrm{O}_{2} \mathrm{~L}^{-1}\right)$.

The dynamic oxygen uptake rate $\left(\mathrm{R}_{\mathrm{S}}, \mathrm{mg} \mathrm{O}_{2} \mathrm{~L}^{-1} \mathrm{~h}^{-1}\right)$ was obtained through the derivation of $\mathrm{DO}$ depending on the time for each respirogram corresponding to the different substrates. The oxygen consumption $(\mathrm{OC}$, $\mathrm{mg} \mathrm{O}_{2} \mathrm{~L}^{-1}$ ) was determined from the numerical integration of $\mathrm{R}_{\mathrm{S}}$ for each addition (dilution) of organic substrate, as shown in Eq. (1):

$$
\mathrm{OC}=\int_{\mathrm{t}_{0}}^{\mathrm{t}} \mathrm{R}_{\mathrm{s}} \mathrm{dt} .
$$

According to Helle [23], the yield coefficient referred to oxygen, $\mathrm{Y}_{\mathrm{O}_{2}}$, is calculated as indicated in Eq. (2):

$$
\mathrm{Y}_{\mathrm{O}_{2}}=\frac{\mathrm{S}-\mathrm{OC}}{\mathrm{S}} \text {. }
$$

The value of $Y_{\text {TSS }}$ was obtained through Eq. (3):

$$
\mathrm{Y}_{\mathrm{TSS}}=\frac{\mathrm{Y}_{\mathrm{O}_{2}}}{\mathrm{f}_{\mathrm{cv}}}
$$

where $\mathrm{f}_{\mathrm{cv}}$ is a conversion factor (1.48 $\mathrm{mg} \mathrm{COD} \mathrm{mg} \mathrm{TSS}^{-1}$ ).

The value of $\mu_{\text {empirical }}$ was determined considering the relation between the cell growth rate $\left(r_{x}, \mathrm{mg} \mathrm{TSS} \mathrm{L}^{-1} \mathrm{~h}^{-1}\right)$ and substrate degradation rate $\left(\mathrm{r}_{\mathrm{su}}, \mathrm{mg} \mathrm{O}_{2} \mathrm{~L}^{-1} \mathrm{~h}^{-1}\right)$, according to Leyva-Díaz et al. [24]. The calculation of $\mathrm{r}_{\mathrm{su}}$ was carried out from the derivation of $S$ depending on the time in Eq. (2). The value of $\mu_{\text {empirical }}$ is shown in Eq. (4):

$$
\mu_{\text {emprical }}=\frac{\mathrm{Y}_{\mathrm{TSS}} \cdot \mathrm{R}_{\mathrm{s}}}{\left(1-\mathrm{Y}_{\mathrm{O}_{2}}\right) \cdot \mathrm{X}_{\mathrm{T}}}
$$

where $\mathrm{X}_{\mathrm{T}}$ is the biomass concentration $\left(\mathrm{mg} \mathrm{TSS} \mathrm{L}^{-1}\right)$.

Biomass concentration was calculated from the $\mathrm{OD}_{600}$ of samples $(2 \mathrm{~mL})$ taken before each addition of substrate. A calibration curve, correlating biomass concentration (as total suspended solids, TSS) and $\mathrm{OD}_{600}$, was prepared using several dilutions of $S$. baltica KB30 biomass. The biomass concentration (TSS) of the various dilutions was analyzed according to the APHA [25].

Equation (5) shows the relation between biomass concentration and $\mathrm{OD}_{600}$ for S. baltica KB30:

$$
\mathrm{X}_{\mathrm{T}}\left(\mathrm{mg} \mathrm{TSS} \mathrm{L}{ }^{-1}\right)=2140.3 \cdot \mathrm{OD}_{600}-325.2
$$

The correlation coefficient $\left(\mathrm{R}^{2}\right)$ between $\mathrm{X}_{\mathrm{T}}$ and $\mathrm{OD}_{600}$ was 0.9995 .

The concentrations of the different substrates, expressed as COD, and the biomass concentrations, measured as TSS, are indicated in Table 1.

The kinetic parameters $\mu_{\mathrm{m}}$ and $\mathrm{K}_{\mathrm{S}}$ were assessed according to the schematic diagram shown in Fig. 1c, as indicated by Leyva-Díaz et al. [24].

The theoretical specific growth rate $\left(\mu_{\text {theoretical }}\right)$ was evaluated for each model by using the Solver add-in facility of Microsoft Office Excel, by considering Eqs. (6)-(9).

The Monod model empirically establishes a saturationtype equation to describe the specific rate of microbial 

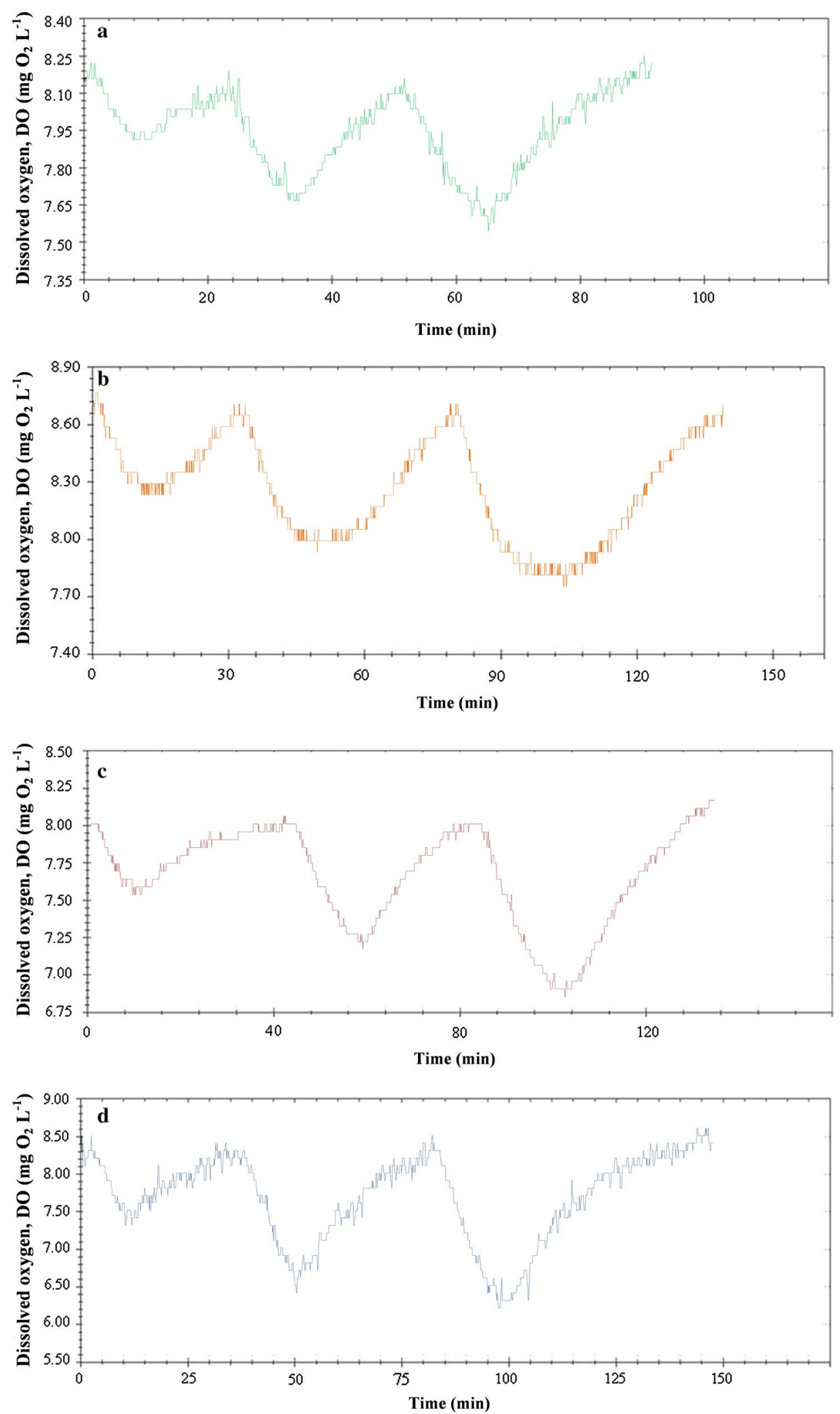

Fig. 2 Time course of dissolved oxygen (DO) in a typical respirometric experiment carried out with Shewanella baltica KB30 for the metabolization of the selected substrates: sodium acetate (a), glucose (b), tween $80(\mathbf{c})$ and peptone (d) 
Table 1 Values of chemical oxygen demand (COD), substrate $(S)$ and biomass $\left(X_{T}\right)$ concentrations for the various dilutions (S1, S2 and S3) of substrates used in the kinetic study

\begin{tabular}{|c|c|c|c|c|}
\hline Substrate & Dilution & $\begin{array}{l}\mathrm{COD} \\
\left(\mathrm{mg} \mathrm{O}_{2} \mathrm{~L}^{-1}\right)\end{array}$ & $\begin{array}{l}\mathrm{S} \\
\left(\mathrm{mg} \mathrm{O}_{2} \mathrm{~L}^{-1}\right)\end{array}$ & $\begin{array}{l}X_{T} \\
\left(\mathrm{mg} \mathrm{TSS} \mathrm{L}^{-1}\right)\end{array}$ \\
\hline \multirow{3}{*}{$\begin{array}{l}\text { Sodium } \\
\text { acetate }\end{array}$} & S1 & 630 & 6.1765 & 306.2 \\
\hline & S2 & 1260 & 12.2330 & 323.3 \\
\hline & S3 & 1800 & 17.3077 & 443.1 \\
\hline \multirow[t]{3}{*}{ Glucose } & S1 & 1190 & 11.6667 & 351.1 \\
\hline & S2 & 2380 & 23.1068 & 374.7 \\
\hline & S3 & 3400 & 32.6923 & 500.9 \\
\hline \multirow[t]{3}{*}{ Tween 80} & S1 & 385 & 3.7745 & 146.6 \\
\hline & S2 & 770 & 7.4757 & 178.7 \\
\hline & S3 & 1100 & 10.5769 & 239.8 \\
\hline \multirow[t]{3}{*}{ Peptone } & S1 & 840 & 8.2353 & 175.6 \\
\hline & S2 & 1680 & 16.3107 & 265.5 \\
\hline & S3 & 2400 & 23.0769 & 284.8 \\
\hline
\end{tabular}

growth in relation to the concentration of a limiting substrate [20], according to Eq. (6):

$$
\mu=\mu_{\mathrm{m}} \frac{\mathrm{S}}{\mathrm{K}_{\mathrm{S}}+\mathrm{S}}
$$

where $\mu$ is the specific growth rate $\left(\mathrm{h}^{-1}\right)$.

A different approach for assessing the kinetic parameters is the Moser model, which is also an unstructured kinetic model (as is the Monod model) and is also based on S [20]. This model is described by Eq. (7):

$$
\mu=\mu_{\mathrm{m}} \frac{S^{\mathrm{n}}}{\mathrm{K}_{\mathrm{S}}+\mathrm{S}^{\mathrm{n}}}
$$

where $n$ is a constant as the exponent of S. The Moser model was studied for $\mathrm{n}=2$.

The Contois model describes an inverse relation between the microbial concentration and its specific growth rate, described by Eq. (8) [27], as the specific growth rate decreases when the microbial concentration increases:

$$
\mu=\mu_{\mathrm{m}} \frac{\mathrm{S}}{\mathrm{K}_{\mathrm{C}} \mathrm{X}_{\mathrm{T}}+\mathrm{S}}
$$

where $\mathrm{K}_{\mathrm{C}}$ is a growth coefficient of the Contois function.

The value of $\mu$ depends on the substrate and biomass concentrations. However, $\mu$ is only a function of $\mathrm{S}$ in the Monod model.

The Tessier model is another unstructured model, which relates $\mu$ and $S$ through an exponential function [28], according to Eq. (9):

$$
\mu=\mu_{\mathrm{m}}\left(1-\mathrm{e}^{-\frac{\mathrm{s}}{\mathrm{K}_{\mathrm{s}}}}\right)
$$

The value of $r_{s u}$ was obtained from the relation between the biomass produced and the substrate consumed indicated through $\mathrm{Y}_{\mathrm{TSS}}$, according to Eq. (10):

$$
r_{\mathrm{su}}=-\frac{\mu \cdot \mathrm{X}_{\mathrm{T}}}{\mathrm{Y}_{\mathrm{TSS}}}
$$

\section{Statistical analysis}

When necessary, data were analyzed with a one-way analysis of variance (ANOVA) and significance of differences was assessed by pair-wise multiple comparison procedure (Tukey test). Statistical analysis was carried out by the software SigmaStat 2.0 (Jandel, San Rafael, CA, USA).

\section{Results and discussion}

The ability of strain KB30 to use a wide array of substrates (95) had been tested by Pesciaroli et al. [22] using the Biolog Microarray System together with those of many other Arctic bacteria. However, the KB30 specific metabolic competences had never been discussed in details and no further investigations, indicating which metabolic choices are favored by the strain, were done. $S$. baltica KB30 was able to degrade a number (37) of carbon sources (Fig. 3) in line with the outcome of Deng et al. [29]. These authors, in the frame of the "Shewanella Federation" consortium, performed an extensive study, carrying out a detailed genetic and physiological characterization of various $S$. baltica strains. They stated that the following carbon sources were used by all studied strains: cis-aconitic acid, sucrose, D-gluconic acid, L-glutamic acid, dextrin, maltose, $\alpha$-D-glucose, L-serine, $N$-acetyl-D-glucosamine, lactic acid, and inosine. Strain KB30 shared these features; most of them were observed also in other S. baltica strains studied by the Biolog Microarray System [9] or by extensive genomic/ metabolic analyses [15]. The use of glycogen, gentiobiose, cellobiose, sucrose, D-gluconate, and citrate, included in the initial description of this species [9], was confirmed for KB30 also. On a numerical basis, the favorite carbon sources were carboxylic acids, carbohydrates and amino acids with 12, 11 and 9 compounds, respectively. However, the number of carbon source used for growth is not sufficient to represent the efficiency of the bacterial metabolism to degrade the different substrates and, consequently, which metabolic pathways could be considered as preferential. For these reasons, the KB30 heterotrophic metabolism was analyzed by respirometric/ kinetic methods, using representative substrates of the mentioned different categories. The selection was also guided by possible potential application of the study.

Table 2 shows the kinetic parameters corresponding to the various models characterizing the biodegradation of the different substrates by S. baltica KB30. The accuracy 


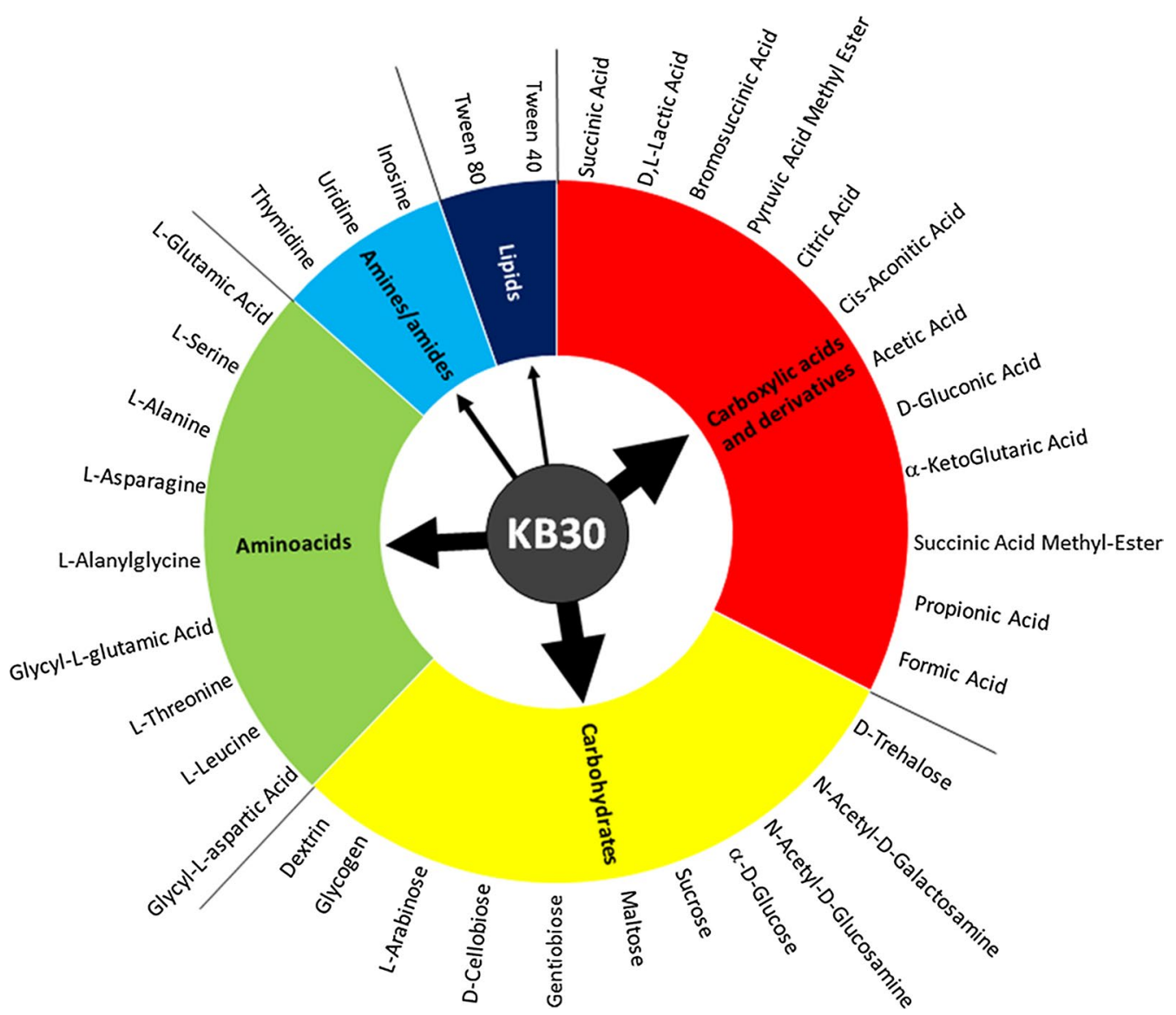

Fig. 3 Degrading ability of Shewanella baltica KB30 regarding different substrate categories (carbohydrates, carboxylic and amino acids, amine/ amides and lipids), as previously determined by the Biolog Microarray system. Arrows'thickness is proportional to the number of substrates used for each category

of the models is given through the LSE values. By applying these models for the kinetics of cell growth and substrate consumption, a description of cellular behavior and substrate degradation was provided under different organic sources [21].

Monod's was the best fitting model to describe the kinetic performance of KB30 in relation to the biodegradation of sodium acetate and tween 80 , as it showed the lowest LSE with values of $1.0661 \times 10^{-6} \mathrm{~h}^{-2}$ and $6.4165 \times 10^{-5} \mathrm{~h}^{-2}$, respectively (Table 2 ). For glucose and peptone, the best adjustment for the kinetic behavior was obtained by the Contois model, showing LSE values of $1.7037 \times 10^{-5} \mathrm{~h}^{-2}$ and $1.9104 \times 10^{-4} \mathrm{~h}^{-2}$, respectively (Table 2). LSE values are often used to determine the quality of model fitting of experimental data (concerning $\mu_{\text {empirical }}$ ), as reported by Annuar et al. for the kinetic modeling of bacteria such as Pseudomonas putida [28].

Very scarce information are available concerning the kinetic performance of Shewanella species in relation to the utilization of various substrates. However, even with the limited existing information, it is possible to underline consistent metabolic differences between strain KB30 and others of same genus. Both the Monod and Moser models were used by Miroliaei et al. [20] to characterize the performance of microbial fuel cells constituted by Shewanella sp. and Escherichia coli, describing their growth and substrate uptake kinetics in batch experiments. The values of $\mu_{\mathrm{m}}$, obtained by these authors for Shewanella sp. regarding glucose metabolization (1.54 and $0.72 \mathrm{~h}^{-1}$ for the Monod and Moser models, respectively), were higher than those obtained in this study for S. baltica $\left(0.0840 \pm 0.0021\right.$ and $0.0811 \pm 0.0020 \mathrm{~h}^{-1}$ for the Monod and Moser models, respectively), as indicated in Table 2. This difference could be related either to different operational and experimental conditions, affecting the bacterial dynamics and metabolism, or to actual diverse metabolic competences between the two strains.

Tang et al. studied Shewanella oneidensis MR-1 in minimal media by biochemical methods [21]. With acetate, they achieved a $\mu_{\mathrm{m}}$ value $\left(0.28 \mathrm{~h}^{-1}\right)$ higher 
Table 2 Kinetic parameters according to the models of Monod, Moser, Contois and Tessier for the characterization of Shewanella baltica KB30 metabolization of the different substrates

\begin{tabular}{|c|c|c|c|c|c|}
\hline Substrate & Model & $\mu_{m}\left(h^{-1}\right)$ & $\mathrm{K}_{\mathrm{S}}\left(\mathrm{mg} \mathrm{O}_{2} \mathrm{~L}^{-1}\right)$ & $\mathrm{Y}_{\mathrm{TSS}}\left(\mathrm{mg}\right.$ TSS $\left.\mathrm{mg} \mathrm{OD}^{-1}\right)$ & $\operatorname{LSE}\left(h^{-2}\right)$ \\
\hline \multirow[t]{4}{*}{ Sodium acetate } & Monod & $0.1163 \pm 0.0029^{a}$ & $4.9267 \pm 0.3518^{\mathrm{a}}$ & $0.6695 \pm 0.0295^{\mathrm{a}}$ & $1.0661 \times 10^{-6}$ \\
\hline & Moser & $0.0946 \pm 0.0024^{\mathrm{a}}$ & $17.8571^{(1)} \pm 1.2750^{\mathrm{a}}$ & & $9.4331 \times 10^{-6}$ \\
\hline & Contois & $0.1385 \pm 0.0035^{a}$ & $0.0230^{(2)} \pm 0.0016^{a}$ & & $3.1754 \times 10^{-5}$ \\
\hline & Tessier & $0.0934 \pm 0.0024^{\mathrm{a}}$ & $5.3119 \pm 0.3793^{\mathrm{a}}$ & & $6.1539 \times 10^{-6}$ \\
\hline \multirow[t]{4}{*}{ Glucose } & Monod & $0.0840 \pm 0.0021^{b}$ & $1.6077 \pm 0.1148^{b}$ & $0.6681 \pm 0.0294^{\mathrm{a}}$ & $2.5382 \times 10^{-5}$ \\
\hline & Moser & $0.0811 \pm 0.0020^{b}$ & $14.3311^{(1)} \pm 1.0232^{\mathrm{a}}$ & & $2.1119 \times 10^{-5}$ \\
\hline & Contois & $0.0886 \pm 0.0022^{b}$ & $0.0071^{(2)} \pm 0.0005^{b}$ & & $1.7037 \times 10^{-5}$ \\
\hline & Tessier & $0.0799 \pm 0.0020^{b}$ & $4.6965 \pm 0.3353^{\mathrm{a}}$ & & $1.7588 \times 10^{-5}$ \\
\hline \multirow[t]{4}{*}{ Tween 80} & Monod & $0.1162 \pm 0.0029^{a}$ & $0.5780 \pm 0.0413^{b}$ & $0.6678 \pm 0.0294^{\mathrm{a}}$ & $6.4165 \times 10^{-5}$ \\
\hline & Moser & $0.1107 \pm 0.0028^{c}$ & $1.3073^{(1)} \pm 0.0933^{b}$ & & $7.4084 \times 10^{-5}$ \\
\hline & Contois & $0.1202 \pm 0.0030^{c}$ & $0.0046^{(2)} \pm 0.0003^{c}$ & & $8.1371 \times 10^{-5}$ \\
\hline & Tessier & $0.1089 \pm 0.0027^{c}$ & $1.3941 \pm 0.0995^{b}$ & & $8.3179 \times 10^{-5}$ \\
\hline \multirow[t]{4}{*}{ Peptone } & Monod & $0.2815 \pm 0.0071^{c}$ & $10.2421 \pm 0.7313^{c}$ & $0.6687 \pm 0.0294^{\mathrm{a}}$ & $7.6023 \times 10^{-4}$ \\
\hline & Moser & $0.2032 \pm 0.0051^{d}$ & $39.9392^{(1)} \pm 2.8517^{c}$ & & $1.0938 \times 10^{-3}$ \\
\hline & Contois & $0.2062 \pm 0.0052^{d}$ & $0.0039^{(2)} \pm 0.0003^{c}$ & & $1.9104 \times 10^{-4}$ \\
\hline & Tessier & $0.2144 \pm 0.0054^{d}$ & $9.6725 \pm 0.6906^{c}$ & & $9.0604 \times 10^{-4}$ \\
\hline
\end{tabular}

The kinetic parameters assessed were $\mu_{\mathrm{m}}$ (maximum specific growth rate), $\mathrm{K}_{\mathrm{S}}$ (substrate half-saturation coefficient) and $\mathrm{Y}_{\text {TSS }}$ (yield coefficient referred to total suspended solids), with the evaluation of LSE (least-squared error). Data are the mean of three replicates ( \pm SD). For each kinetic model, column means followed by the same superscript letter were not significantly different $(P>0.01)$ as determined by the Tukey test

(1) $\mathrm{K}_{\mathrm{S}}\left(\mathrm{mg} \mathrm{O}_{2} \mathrm{~L}^{-1}\right)^{2}$ in the Moser model (for $\left.\mathrm{n}=2\right)$

(2) $\mathrm{K}_{\mathrm{C}}\left(\mathrm{mg} \mathrm{O}_{2} \mathrm{mg} \mathrm{TSS}^{-1}\right)$ replaces $\mathrm{K}_{\mathrm{S}}$ in the Contois model

than those obtained in this study, which ranged from $0.0934 \pm 0.0024$ to $0.1385 \pm 0.0035 \mathrm{~h}^{-1}$ (Table 2). Thus, S. oneidensis MR-1 metabolizes acetate faster than S. baltica KB30.

Considering the different kinetic models, consumption of each substrate was analyzed through $r_{s u}$, as observed in Fig. 4. The bacterium clearly degraded the various organic compounds at different rates: for all the kinetic models analyzed, $r_{\mathrm{su}}$ was highest with peptone, followed by tween 80 , sodium acetate and glucose (Fig. 4 ). $\mu_{\mathrm{m}}$ is the maximum specific growth rate on a given substrate. Its lowest value for glucose indicated that this compound was biodegraded more slowly than the other substrates, as $r_{\mathrm{su}}$ is directly proportional to $\mu_{\mathrm{m}}$, according to Eqs. (6)-(10). Therefore, the assimilation of peptone was faster than that of the other carbon sources. Peptone is an organic substrate (protein hydrolysate) containing nitrogen sources such as free amino acids and oligopeptides. Therefore, in strain KB30 proteolytic metabolism was probably faster than lipolytic and glucidic metabolism, as confirmed by the respirometry results related to tween 80 and glucose (Fig. 4). Bacteria with very high proteolytic capacity, accompanied by extremely scarce ability to degrade sugars and related compounds, are known, as shown by Juárez-Jiménez et al. for Delftia tsuruhatensis BM90, which is practically unable to degrade carbohydrates [30]. Strain KB30 is known for its ability to use a complex pattern of carbon sources including various sugars, amino acids, lipids and organic acids, showing a marked composite metabolism [22], but the respirometry results suggest that its proteolytic pathways could be favored. On the other hand, the faster metabolism on peptone could be justified by the higher bioavailability of its nitrogen sources, if compared with that contained in $\mathrm{M} 9\left(\mathrm{NH}_{4} \mathrm{Cl}\right)$.

The rather good capacity of strain KB30 to metabolize lipids, even with a lower rate than that of peptone (Fig. 4), could find exploitation in biotechnology. An interesting application for environmental issues would be the biological removal of pollutant compounds chemically correlated to tween $80\left(\mathrm{C}_{64} \mathrm{H}_{124} \mathrm{O}_{26}, \mathrm{PM} 1310 \mathrm{~g} \mathrm{~mol}^{-1}\right)$, such as surfactants and/or emulsifiers. Since KB30 is able to use a wide pattern of lipids and/or fatty acids [22], this applicative potential would be even higher.

The pattern obtained by the kinetic study indicated that carbohydrate metabolism of strain KB30 was rather slow, as shown by the lowest value of $r_{\mathrm{su}}$ for glucose (Fig. 4).

The kinetic results obtained in this work somehow reflect those stated by Pesciaroli concerning the strain KB30 extracellular enzyme pattern [31]. The bacterium was able to produce proteases and lipases, while no production of hydrolytic enzymes targeting natural polysaccharides (such as cellulose, starch, pectin and chitin) was detected. This probably suggests that its role in nature is 

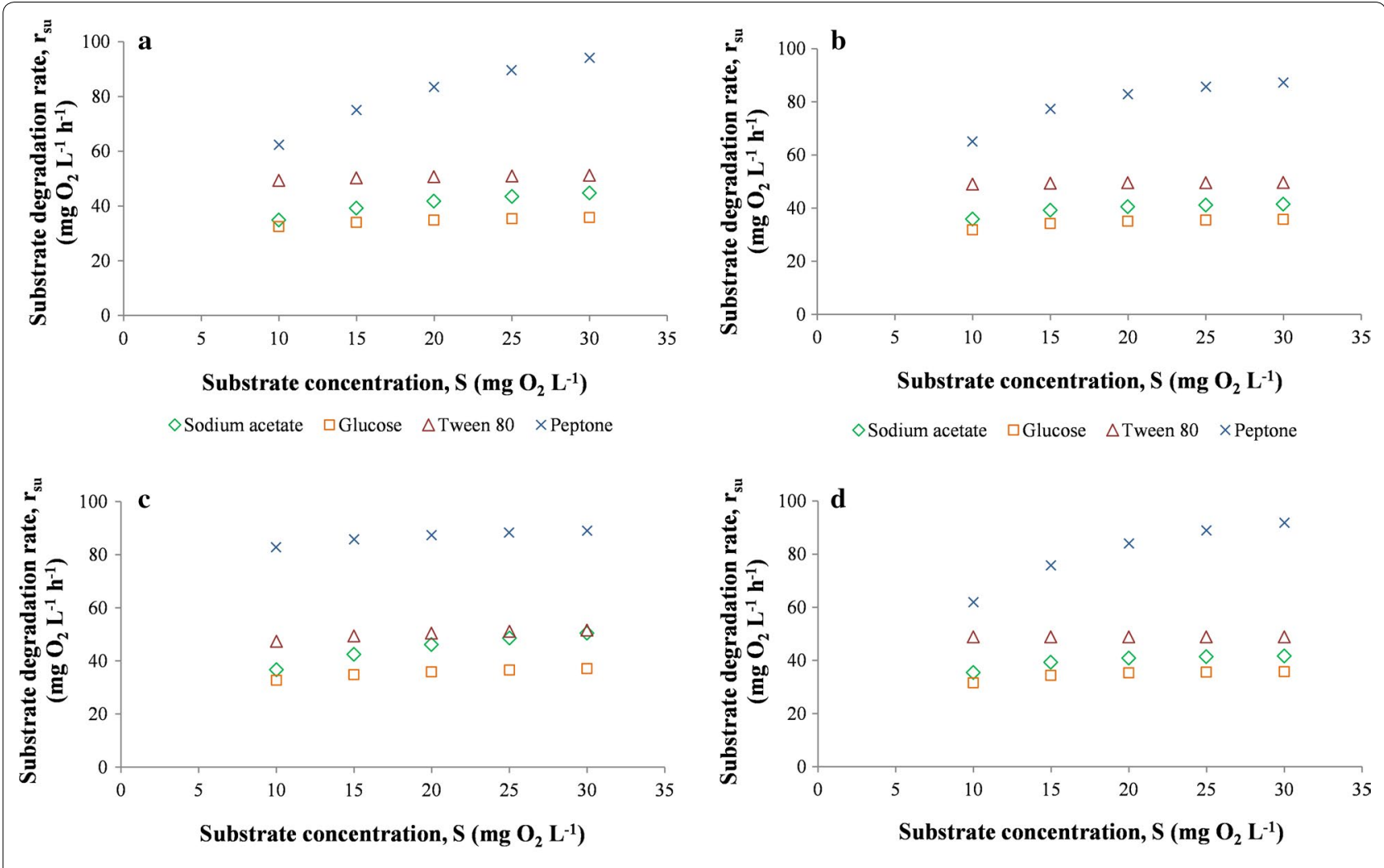

$\diamond$ Sodium acetate $\square$ Glucose $\triangle$ Tween $80 \times$ Peptone

$\diamond$ Sodium acetate $\square$ Glucose $\triangle$ Tween $80 \times$ Peptone

Fig. 4 Substrate degradation rate $\left(r_{\text {su }}\right)$ of Shewanella baltica KB30 during the respirometric experiments in relation to substrate concentration (S), measured as chemical oxygen demand in $\left(\mathrm{mg} \mathrm{O}_{2} \mathrm{~L}^{-1}\right)$, obtained by different models: Monod (a), Moser (b), Contois (c) and Tessier (d)

more oriented to the mineralization and recycling of proteic and lipidic matrices than to carbohydrates and glucidic substrates.

The bacterial growth was also evaluated through $r_{x}$ for the consumption of the various organic sources, as observed in Fig. 5. The highest $r_{x}$ was obtained during degradation of peptone for all the kinetic models studied, as the values of $Y_{\text {TSS }}$ were similar for the different substrates used. Therefore, the highest concentration of biomass produced by $S$. baltica $\mathrm{KB} 30$, measured as $\mathrm{X}_{\mathrm{T}}$ depending on time, was recorded on peptone.

\section{Conclusions}

This work represented the first attempt to characterize the kinetic performance of $S$. baltica during its growth on various carbon sources using several models. Actually, the use of different models, allowing best fitting for the consumption of each substrate, permitted a comprehensive approach to the question. The biodegradation of sodium acetate and tween 80 was best fitted to Monod's model while the Contois' showed the best adjustment of the experimental data for glucose and peptone utilization. As stated by the kinetic parameters, biodegradation of peptone was faster than that of the other carbon sources. Thus in S. baltica KB30, proteolytic metabolism appeared to be favored compared to lipidic and glucidic metabolism. The foregoing statements suggest that, in natural environments, S. baltica KB30 would contribute much more to the mineralization and recycling of protein and lipid than carbohydrates. In addition, its rather great competence in metabolizing lipids could find use in environmental issues (bioremediation), such as the removal of surfactants and/or emulsifiers. On the whole, the results obtained in this work contribute to fill a gap in the 

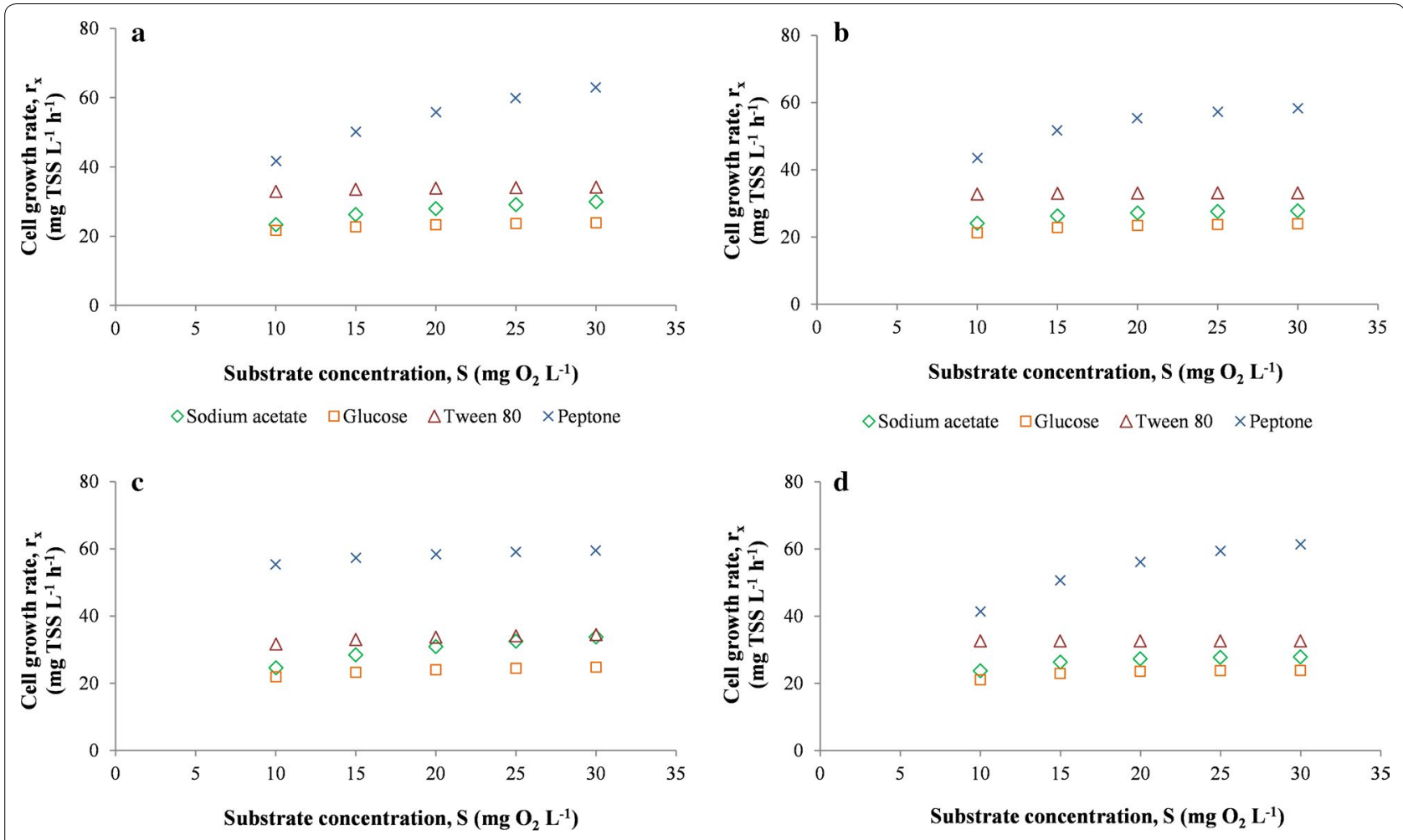

$\diamond$ Sodium acetate $\quad \square$ Glucose $\triangle$ Tween $80 \times$ Peptone

$\diamond$ Sodium acetate $\quad \square$ Glucose $\triangle$ Tween $80 \times$ Peptone

Fig. 5 Cell growth rate $\left(r_{x}\right)$ of Shewanella baltica KB30 during the respirometric experiments in relation to substrate concentration ( $S$ ), measured as chemical oxygen demand in ( $\left.\mathrm{mg} \mathrm{O}_{2} \mathrm{~L}^{-1}\right)$, obtained by different models: Monod (a), Moser (b), Contois (c) and Tessier (d)

knowledge of this metabolically interesting cold-adapted microorganism, which deserves to be studied in view of possible applications. Studies in this sense are currently in course.

\section{Abbreviations}

ANOVA: one-way analysis of variance; COD: chemical oxygen demand (mg $\mathrm{O}_{2} \mathrm{~L}^{-1}$ ); DEB: Department of Ecological and Biological Sciences, University of Tuscia; DO: dissolved oxygen ( $\left.\mathrm{mg} \mathrm{O}_{2} \mathrm{~L}^{-1}\right)$; $\mathrm{K}_{\mathrm{c}}$ : growth coefficient of the Contois function ( $\mathrm{mg} \mathrm{O}_{2} \mathrm{mg} \mathrm{TSS}^{-1}$ ); $\mathrm{K}_{\mathrm{s}}$ : substrate half-saturation coefficient ( $\mathrm{mg} \mathrm{O}_{2} \mathrm{~L}^{-1}$ ); LSE: least-squared error $\left(\mathrm{h}^{-2}\right)$; OC: oxygen consumption $\left(\mathrm{mg} \mathrm{O}_{2} \mathrm{~L}^{-1}\right) ; \mathrm{OD}_{600}$ : optical density at $600 \mathrm{~nm}$; PCA: plate count agar; $\mathrm{R}_{\mathrm{S}}$ : dynamic oxygen uptake rate $\left(\mathrm{mg} \mathrm{O}_{2} \mathrm{~L}^{-1} \mathrm{~h}^{-1}\right)$; $\mathrm{r}_{\text {su }}$ : substrate degradation rate ( $\mathrm{mg} \mathrm{O}_{2} \mathrm{~L}^{-1} \mathrm{~h}^{-1}$ ); $\mathrm{r}_{\mathrm{x}}$ : cell growth rate $\left(\mathrm{mg} \mathrm{TSS} \mathrm{L}^{-1} \mathrm{~h}^{-1}\right.$ ); S: substrate concentration ( $\mathrm{mg} \mathrm{O}_{2} \mathrm{~L}^{-1}$ ); S. baltica: Shewanella baltica; SD: standard deviation; S. oneidensis: Shewanella oneidensis; TSS: total suspended solids (mg TSS L $\left.{ }^{-1}\right)$; $\mathrm{X}_{\mathrm{T}}$ : biomass concentration ( $\mathrm{mg} \mathrm{TSS}^{-1}$ ); $\mathrm{Y}_{\mathrm{O} 2}$ : yield coefficient referred to oxygen; $\mathrm{Y}_{\mathrm{TSS}}$ : yield coefficient referred to the total suspended solids ( $\mathrm{mg} \mathrm{TSS} \mathrm{mg} \mathrm{COD}^{-1}$ ); $\mu$ : specific growth rate $\left(h^{-1}\right)$; $\mu_{\text {empirical }}$ empirical specific growth rate $\left(h^{-1}\right) ; \mu_{m}$ : maximum specific growth rate $\left(\mathrm{h}^{-1}\right) ; \mu_{\text {theoretical }}$ theoretical specific growth rate $\left(h^{-1}\right)$.
\end{abstract}

\section{Authors' contributions}

JCLD, JMP and MF conceived and designed the experiments. JCLD and SG performed the experiments. JCLD, SG and MF analyzed the data. PB and MF contributed reagents, materials and analysis tools. JCLD wrote the manuscript. $J C L D, P B$ and MF planned the graphical features of the manuscript. JCLD, JMP, $P B, S G$ and $M F$ revised the manuscript. All authors read and approved the final manuscript.

\section{Author details}

${ }^{1}$ Department of Civil Engineering, University of Granada, 18071 Granada, Spain. ${ }^{2}$ Institute for Water Research, University of Granada, 18071 Granada, Spain. ${ }^{3}$ Department of Ecological and Biological Sciences, University of Tuscia, Largo Università snc, 01100 Viterbo, Italy. ${ }^{4}$ Laboratory of Applied Marine Microbiology, ConISMa, University of Tuscia, 01100 Viterbo, Italy.

\section{Acknowledgements}

The research was supported by the Department of Ecological and Biological Sciences of the University of Tuscia. The authors wish to thank the Ministry of Education, Culture and Sport of Spain for its contribution in the framework of Becas del Programa de Formación de Profesorado Universitario (FPU) awarded to J.C. Leyva-Díaz (Grant AP2010-1552), as well as the University of Granada in the training plan "Programa de Ayudas Puente" and the program "Convocatoria de ayudas a Proyectos de I+D Excelencia 2013" (CTM2013-48154-P).

\section{Competing interests}

The authors declare that they have no competing interests.

\section{Availability of data and materials}

The authors promise the availability of supporting data.

\section{Consent for publication}

The authors provide consent for publication.

Ethics approval and consent to participate

Not applicable.

\section{Funding}

Not applicable. 


\section{Publisher's Note}

Springer Nature remains neutral with regard to jurisdictional claims in published maps and institutional affiliations.

Received: 14 July 2017 Accepted: 31 October 2017

Published online: 03 November 2017

\section{References}

1. Shewan JM, Hobbs G, Hodgkiss W. A determinative scheme for the identification of certain genera of Gram-negative bacteria with special reference to Pseudomonodaceae. J Appl Bacteriol. 1960;23:379-90.

2. Macdonell MT, Colwell RR. Phylogeny of the Vibrionaceae and recommendation for two new genera Listonella and Shewanella. Syst Appl Microbiol. 1985;6:171-82.

3. Ivanova EP, Flavier S, Christen R. Phylogenetic relationships among marine Alteromonas-like proteobacteria: emended description of the family Alteromonadaceae and proposal of Pseudoalteromonadaceae fam. nov., Colwelliaceae fam. nov., Shewanellaceae fam. nov., Moritellaceae fam. nov., Ferrimonadaceae fam. nov., Idiomarinaceae fam. nov. and Psychromonadaceae fam. nov. Int J Syst Evol Microbiol. 2004;54(5):1773-88.

4. Dikow RB. Genome-level homology and phylogeny of Shewanella (Gammaproteobacteria: Iteromonadales: Shewanellaceae). BMC genomics. 2011;12(1):1.

5. Bowman JP, McCammon SA, Nichols DS, Skerratt JH, Rea SM, Nichols PD, McMeekin TA. Shewanella gelidimarina sp. nov. and Shewanella frigidimarina sp. nov., novel Antarctic species with the ability to produce eicosapentaenoic acid (20:5w3) and grow anaerobically by dissimilatory Fe(III) reduction. Int J Syst Bacteriol. 1997;47:1040-7.

6. Ivanova EP, Sawabe T, Gorshkova NM, Svetashev VI, Mikhailov WV, Nicolau DV, Christen R. Shewanella japonica sp. nov. Int I Syst Evol Microbiol. 2001;51:1027-33.

7. Vogel BF, Venkateswaran K, Satomi M, Gram L. Identification of Shewanella baltica as the most important $\mathrm{H}_{2} \mathrm{~S}$-producing species during iced storage of Danish marine fish. Appl Environ Microbiol. 2005;71(11):6689-97.

8. Pesciaroli C, Cupini F, Selbmann L, Barghini P, Fenice M. Temperature preferences of bacteria isolated from seawater collected in Kandalaksha Bay, White Sea, Russia. Polar Biol. 2012;35(3):435-45.

9. Ziemke F, Höfle MG, Lalucat J, Rosselló-Mora R. Reclassification of Shewanella putrefaciens Owen's genomic group II as Shewanella baltica sp. nov. Int J Syst Bacteriol. 1998;48:179-86.

10. Tryfinopoulou P, Tsakalidou E, Vancanneyt M, Hoste B, Swings J, Nychas GJE. Diversity of Shewanella population in fish Sparus aurata harvested in the Aegean Sea. J Appl Microbiol. 2007;103:711-21.

11. Serio A, Fusella GC, López CC, Sacchetti G, Paparella A. A survey on bacteria isolated as hydrogen sulfide-producers from marine fish. Food Control. 2014;39:111-8.

12. Gram L, Huss HH. Microbiological spoilage of fish and fish products. Int J Food Microbiol. 1996;33:121-37.

13. Tryfinopoulou P, Tsakalidou E, Nychas GJ. Characterization of Pseudomonas spp. associated with spoilage of gilt-head sea bream stored under various conditions. Appl Environ Microbiol. 2002;68:65-72.

14. Gu Q, Fu L, Wang Y, Lin J. Identification and characterization of extracellular cyclic dipeptides as quorum-sensing signal molecules from Shewanella baltica, the specific spoilage organism of Pseudosciaena crocea during $4{ }^{\circ} \mathrm{C}$ storage. J Agric Food Chem. 2013;61 (47):11645-52.

15. Caro-Quintero A, Auchtung J, Deng J, Brettar I, Höfle M, Tiedje JM, Konstantinidis KT. Genome sequencing of five Shewanella baltica strains recovered from the oxic-anoxic interface of the Baltic Sea. J Bacteriol. 2012;194(5):1236

16. Rodionov DA, Yang C, Li X, Rodionova IA, Wang Y, Obraztsova AY, Zagnitko OP, Overbeek R, Romine MF, Reed S, Fredrickson JK, Nealson KH, Osterman AL. Genomic encyclopedia of sugar utilization pathways in the Shewanella genus. BMC Genom. 2010;11(1):494.
17. Rongsayamanont C, Limpiyakorn T, Law B, Khan E. Relationship between respirometric activity and community of entrapped nitrifying bacteria: implications for partial nitrification. Enzyme Microb Technol. 2010;46:229-36.

18. Spanjers $H$, Takacs I, Brouwer $H$. Direct parameter extraction from respirograms for wastewater and biomass characterization. Water Sci Technol. 1999:39(4):137-45.

19. Oliveira CS, Ordaz A, Ferreira EC, Alves M, Thalasso F. In situ pulse respirometric methods for the estimation of kinetic and stoichiometric parameters in aerobic microbial communities. Biochem Eng J. 2011;58-59:12-9.

20. Miroliaei MR, Samimi A, Mohebbi-Kalhori D, Khorram M. Kinetics investigation of diversity cultures of E. coli and Shewanella sp., and their combined effect with mediator on MFC performance. J Ind Eng Chem. 2015;25:42-50

21. Tang YJ, Meadows AL, Keasling JD. A kinetic model describing Shewanella oneidensis MR-1 growth, substrate consumption, and product secretion. Biotechnol Bioeng. 2007;96(1):125-33

22. Pesciaroli C, Barghini P, Cerfolli F, Bellisario B, Fenice M. Relationship between phylogenetic and nutritional diversity in Arctic (Kandalaksha Bay) seawater planktonic bacteria. Ann Microbiol. 2015;65:2405-14.

23. Helle S. A respirometric investigation of the activated sludge treatment of BKME during steady state and transient operating conditions. Ph.D. thesis. University of British Columbia; 1999.

24. Leyva-Díaz JC, Calderón K, Rodríguez FA, González-López J, Hontoria E, Poyatos JM. Comparative kinetic study between moving bed biofilm reactor-membrane bioreactor and membrane bioreactor systems and their influence on organic matter and nutrients removal. Biochem Eng J. 2013;77:28-40.

25. APHA. Standard methods for the examination of water and wastewater 22nd ed. Washington DC: American Public Health Association; 2012.

26. Sönmezişik $M$, Tanyolaç $D$, Şeker $\$$, Tanyolaç $A$. The double-substrate growth kinetics of Sulfolobus solfataricus, a thermophilic sulfur-removing archeabacterium. Biochem Eng J. 1998;1:243-8.

27. Wang Z-W, Li Y. A theoretical derivation of the Contois equation for kinetic modelling of the microbial degradation of insoluble substrates. Biochem Eng J. 2014;82:134-8.

28. Annuar MSM, Tan IKP, Ibrahim S, Ramachandran KB. A kinetic model for growth and biosynthesis of medium-chain-length poly-(3-hydroxyalkanoates) in Pseudomonas putida. Braz J Chem Eng. 2008;25(2):217-28.

29. Deng J, Brettar I, Luo C, Auchtung J, Konstantinidis KT, Rodrigues JL, Höfle M, Tiedje JM. Stability, genotypic and phenotypic diversity of Shewanella baltica in the redox transition zone of the Baltic Sea. Environ Microbiol. 2014;16(6):1854-66.

30. Juárez-Jiménez B, Manzanera M, Rodelas B, Martínez-Toledo MV, González-López J, Crognale S, Perciaroli C, Fenice M. Metabolic characterization of a strain (BM90) of Delftia tsuruhatensis showing highly diversified capacity to degrade low molecular weight phenols. Biodegradation. 2010;21:475-89.

31. Pesciaroli C. Characterization of bacterial communities from seawater samples: the study case of Kandalaksha Bay, Russia. Ph.D. thesis. University of Tuscia; 2011

\section{Submit your next manuscript to BioMed Central and we will help you at every step:}

- We accept pre-submission inquiries

- Our selector tool helps you to find the most relevant journal

- We provide round the clock customer support

- Convenient online submission

- Thorough peer review

- Inclusion in PubMed and all major indexing services

- Maximum visibility for your research

Submit your manuscript at www.biomedcentral.com/submit 